Artikel Penelitian

\title{
Pengembangan Produk Sambal Andaliman (Zanthoxylum acanthopodium DC) Berkemasan Retort pouch: Studi Karakteristik Fisik, Kimia dan Sensoris
}

\author{
Product Development of Andaliman (Zanthoxylum acanthopodium DC) Chili Sauce With Retort pouch \\ Packaging: Physical, Chemical, and Sensory Characteristic Studies
}

Lasuardi Permana*, Hesti Ayuningtyas Pangastuti, Vita Fitriani, Dea Tio Mareta, Amalia Wahyuningtyas

Program Studi Teknologi Pangan, Jurusan Teknologi Produksi dan Industri, Institut Teknologi Sumatera, Lampung Selatan

*Korespondensi dengan penulis (lasuardi.permana@tp.itera.ac.id)

Artikel ini dikirim pada tanggal 19 Maret 2020 dan dinyatakan diterima tanggal 28 Februari 2021. Artikel ini juga dipublikasi secara online https://ejournal2.undip.ac.id/index.php/jatp. Hak cipta dilindungi undang-undang. Dilarang diperbanyak untuk tujuan komersial.

Diproduksi oleh Indonesian Food Technologists (B) (C2021

\begin{abstract}
Abstrak
Sambal andaliman (Zanthoxylum acanthopodium DC) adalah sambal khas dari Sumatera Utara, Indonesia. Produk sambal andaliman instan berkemasan retort pouch merupakan produk pangan lokal yang diinovasi agar memiliki masa simpan yang panjang namun masih dalam kualitas yang baik. Perlakuan sterilisasi dan penambahan asam, perlu dilakukan untuk menambah masa simpannya akan tetapi perlu mempertahankan kualitas sensorinya. Penelitian ini bertujuan untuk mengetahui kombinasi lama sterilisasi dan konsentrasi asam sitrat terbaik terhadap karakterisasi sifat fisik, kimia, dan sensoris sambal andaliman. Metode pembuatan produk sambal dilakukan dengan pengukusan cabai, bawang merah, bawang putih, dan tomat yang difinalisasi dengan tahap penghalusan. Hasil penelitian menunjukkan bahwa sambal andaliman terbaik dilihat dari parameter kadar air, $\mathrm{pH}$, aktivitas air, viskositas, dan warna adalah sambal dengan perlakuan: (1) lama sterilisasi 35 menit dan asam sitrat 5\% (b/b) dan (2) lama sterilisasi 35 menit dan asam sitrat $3 \%$. Berdasarkan hasil analisis sensoris yang dilakukan pada sambal terpilih bersama dengan sambal kontrol, diketahui bahwa seluruh parameter sensoris menunjukkan hasil yang tidak berbeda nyata, kecuali parameter rasa. Kesimpulannya, sambal terbaik pada penelitian ini adalah sambal dengan lama sterilisasi 35 menit dan asam sitrat $3 \%$. Informasi ini sangat bermanfaat bagi wirausaha dibidang sambal khas untuk dapat memperpanjang masa simpan namun tetap mempertahankan kualitas sensorinya.
\end{abstract}

Kata kunci: andaliman, asam sitrat, retort, sambal, sterilisasi

\begin{abstract}
Andaliman (Zanthoxylum acanthopodium DC) is traditional chili sauce from North Sumatera, Indonesia. Andaliman chili sauce prepared with retort pouch has known as local food product that was developed to have long shelf life but remaining good quality. Sterilzation and acid fortification were commonly used in manufacture, therefore the purpose of this research was to understand the best combination of sterilization time and citric acid concentration to Andaliman chili sauce's physical, chemical, and sensory characteristics. Chili sauce was done by steaming fresh chili, onion, garlic, and tomato and followed by grinding. The research showed that the best andaliman chili sauce seeing from several parameter such as moisture content, $\mathrm{pH}$, water activity, viscosity, and color was chili sauce with treatment of: (1) 35-minute sterilization time and 5\% (w/W) citric acid concentration; and (2) 35-minute sterilization time and 3\% citric acid concentration. Based on sensory analysis in two selected chili sauce and other chili sauce as controls, it has been discovered that all of the sensory parameter showed no significance, except taste parameter. As conclusion, the best andaliman chili sauce in this research was product with combination of 35-minutes sterilization time and 3\% citric acid concentration. This information may open the knowledge to chili sauce producer to enhance the shelf life but keep maintaining good quality.
\end{abstract}

Keywords: andaliman, chili sauce, citric acid, retort sterilization

\section{Pendahuluan}

Andaliman (Zanthixylum acanthopodium DC) adalah tumbuhan semak belukar yang masuk ke famili Rutaceae yang hidup liar secara endemik di Sumatera Utara, Indonesia (Hsuan, 1978). Selain di Indonesia, tanaman ini juga tersebar di berbagai Negara, meliputi India Utara, Nepal, Cina, Pakistan, Myanmar, dan Thailand (Harahap dan Silaban, 2019). Buah andaliman memiliki aroma spesifik kuat dan memiliki rasa sepat-pahit mirip jeruk yang dapat menstimulasi sekresi saliva (Suryanto et al., 2004). Kuatnya aroma andaliman berasal dari senyawa aromatik geranil asetat dan limonen (Wijaya et al., 2018). Tanaman ini juga mengandung senyawa antimikroba dan antioksidan, dan diduga dapat mencegah penyakit, misalnya diabetes mellitus (Gardjito, 2013; 
Suryanto et al., 2004; Wijaya et al., 2018; Ridho dan Lindarto, 2018).

Andaliman telah digunakan secara luas sebagai bumbu dalam masakan suku Batak, misalnya pada arsik (ikan mas yang dimasak dan dibumbui), tombur (pelengkap ikan berbumbu), naniura (ikan mas yang tidak dimasak maupun fermentasi), dan napinadar (ikan atau daging panggang) (Napitupulu et al., 2004). Salah satu produk olahan andaliman dalam produk sambal. Sambal andaliman dibuat dari campuran bahan-bahan, antara lain andaliman, cabai hijau, bawang merah, bawang putih, andaliman, jeruk nipis, kemiri, serai, tomat hijau, kemiri, gula, dan garam.

Sebagai pangan tradisional Sumatera Utara, sambal andaliman layak menjadi ikon yang dapat dikomersialisasi secara luas. Sayangnya, sambal memiliki umur simpan yang relatif rendah, yaitu hanya beberapa hari untuk sambal matang, bahkan lebih pendek untuk sambal mentah (Gardjito et al, 2017). Tingginya konsumen yang menginginkan sambal dengan kemasan praktis membuat banyak produsen sambal instan dalam jar yang menggunakan pengawet buatan seperti natrium benzoat untuk mempertahankan umur simpannya. Pengemasan sambal dalam jar dapat meningkatkan umur simpannya mulai 3 hingga 6 bulan (Wardhani et al., 2020).

Inovasi pengemasan dapat dilakukan dengan menggunakan retort (Bindu et al., 2005; Rajan et al., 2014; Al-Baali dan Farid, 2006). Teknologi retort telah dikembangkan, mengingat keunggulannya dalam hal penampilan, kepraktisan, dan umur simpan (Topno et al., 2011; Holanda et al., 2018; Apichartsrangkoon et al., 2012). Produk retort yang disimpan pada suhu $27^{\circ} \mathrm{C}$ dapat bertahan selama 76 bulan (Robertson, 2006). Peningkatan umur simpan dapat juga dilakukan dengan penambahan asam sitrat ke dalam retort pouch. Selain dapat menurunkan $\mathrm{pH}$ yang mempengaruhi umur simpan produk, penggunaan asam lemah seperti asam sitrat dapat mencegah browning enzimatik dan non-enzimatik (Chaethong dan Ponsawatmanit, 2015). Penelitian ini bertujuan untuk mengetahui pengaruh lama sterilisasi dan penambahan asam sitrat terhadap karakteristik fisik, kimia, dan sensoris sambal andaliman yang dikemas dalam retort pouch. Manfaat yang didapat dari penelitian ini adalah diperolehnya informasi mengenai lama sterilisasi dan perlakuan asam untuk mendapatkan produk yang mempunyai masa simpan panjang namun tetap terjaga kualitasnya.

\section{Materi dan Metode}

Materi

Bahan yang digunakan dalam pembuatan produk sambal antara lain cabai hijau kecil, cabai hijau besar, bawang merah, bawang putih, andaliman, jeruk nipis, serai, tomat hijau, kemiri, gula, garam, minyak goreng, asam sitrat, yang diperoleh di pasar tradisional Way Kandis, Bandar Lampung dan kemasan retort pouch aluminium foil ukuran $20 \times 20 \mathrm{~cm}$ dengan ketebalan 120 mikron yang dibeli di toko bahan kue Aladin, Bandar Lampung. Bahan yang digunakan untuk analisis produk selama penelitian antara lain aquades dan larutan buffer natrium fosfat.

Alat yang digunakan untuk analisis adalah timbangan (Ohaus, USA), chromameter (Konica Minolta CR-400, Japan), oven (Memmert, Germany), pH meter (Hanna, Germany), viskometer (Brookfield DV-1, Ametek, USA), Aw meter (Pawkit-Decagon, USA), dan booth untuk uji sensoris.

\section{Metode}

Penelitian dilaksanakan pada kurun waktu pada bulan April-Desember 2019 dan dilakukan di Laboratorium Kimia, Institut Teknologi Sumatera, Laboratorium Teknologi Hasil Pertanian Politeknik Negeri Lampung, serta Laboratorium Rekayasa Proses Pengolahan Pangan, Universitas Gadjah Mada.

\section{Desain Percobaan}

Penelitian dilakukan menggunakan Rancangan Acak Lengkap Faktorial yang terdiri dari dua faktor, yaitu waktu sterilisasi dan konsentrasi asam sitrat. Faktor pertama, yaitu waktu sterilisasi terdiri dari 2 level faktor, yaitu 20 menit dan 35 menit, sedangkan faktor kedua adalah konsentrasi asam sitrat dengan level faktor yaitu kadar sebesar 0,$1 ; 0,3$ dan $0,5 \%(b / b)$. Percobaan dilakukan dengan 2 kali ulangan percobaan dan 2 kali ulangan analisis.

\section{Tahapan Penelitian}

Tahapan penelitian dilakukan menjadi 3 bagian, yaitu: (1) penelitian utama, (2) pemilihan perlakuan terbaik, dan (3) analisis sensoris. Pada penelitian utama, dilakukan pengujian kadar air, $\mathrm{pH}$, aktivitas air, viskositas, dan warna dengan enam kombinasi perlakuan. Data pengujian kemudian diolah untuk menentukan dua sambal terbaik menggunakan metode indeks efektivitas. Dua sambal terbaik kemudian dilakukan analisis sensoris bersama dengan sambal kontrol (sambal andaliman tanpa sterilisasi dan tanpa asam sitrat), dan sambal dengan sterilisasi (tanpa asam sitrat) untuk menemukan satu kombinasi perlakuan terbaik.

Metode pembuatan produk sambal andaliman mengacu pada penelitian Sonangda et al. (2019) dengan modifikasi. Pembuatan produk dimulai dari pengukusan cabai, bawang merah, bawang putih, dan tomat pada suhu $80^{\circ} \mathrm{C}$ selama 2 menit. Cabai kemudian dihaluskan dengan blender (Philips HR 2115, Holland) dan ditambah dengan bumbu halus. Campuran bahan kemudian dilakukan proses pemanasan disertai pengadukan selama 30 menit. Bahan dibiarkan turun suhunya hingga $75^{\circ} \mathrm{C}$, kemudian ditambahkan asam sitrat sesuai konsentrasi perlakuan, dan selanjutnya dilakukan pengemasan ke dalam retort pouch. Proses pengemas pada penelitian ini dilakukan secara sempurna (tanpa kerut dan delaminasi). 
Penyegelan dilakukan menyeluruh tanpa terjadi kerusakan.

Setelah dikemas, bahan kemudian disterilisasi pada suhu $121^{\circ} \mathrm{C}$ dengan dua variabel waktu (20 menit dan 35 menit) menggunakan sterilizator uap bertekanan tinggi (Tomy SX-500, Japan), dan dilanjutkan dengan pendinginan cepat pada air mengalir. Produk sambal kemasan retort pouch kemudian dianalisis sifat fisik, kimia, dan organoleptiknya.

\section{Prosedur Analisis}

Analisis sifat kimia yang dilakukan adalah analisis kadar air dan $\mathrm{pH}$. Pengujian kadar air dilakukan dengan metode AOAC (2000). Pengujian $\mathrm{pH}$ dilakukan dengan $\mathrm{pH}$ meter (Starter 3000, OHAUS, USA). Analisis sifat fisik yang dilakukan adalah aktivitas air, viskositas, dan warna. Pengujian aktivitas air dilakukan dengan Aw meter, viskositas menggunakan viskometer (Model RVT Serial 105202, Brookfield, USA), serta warna menggunakan colorimeter. Prosedur pengujian aktivitas air dan viskositas dilakukan berdasarkan petunjuk alat tersebut. Analisis sensoris dilakukan menggunakan uji hedonik dengan melibatkan 35 panelis (Lim, 2011).

\section{Pemilihan Perlakuan Terbaik}

Pemilihan perlakuan terbaik dilakukan menggunakan metode indeks efektivitas DeGarmo et al. (1984). Pemilihan dilakukan untuk mencari 2 (dua) perlakuan sambal terbaik yang akan dilanjutkan ke tahap kedua, yaitu uji sensoris. Metode indeks efektivitas merupakan metode pembobotan dimana setiap parameter yang diukur akan ditimbang tingkat kepentingannya. Tingkat kepentingan dalam setiap parameter dijelaskan pada Tabel 1.

\section{Analisis Sensoris}

Analisis sensoris dilakukan dengan menguji sambal kontrol (sambal andaliman tanpa sterilisasi dan tanpa asam sitrat), dan sambal dengan sterilisasi (tanpa asam sitrat) ditambah dengan dua sambal perlakuan terbaik yang didapat dari metode indeks efektivitas. Analisis sensoris dilakukan menggunakan uji hedonik dengan melibatkan 35 panelis semi terlatih (Lim, 2011). Variabel pengamatan pada uji sensoris meliputi warna, tekstur, aroma, rasa, dan keseluruhan secara umum dengan menggunakan skor 1 sampai $9(1=$ amat sangat tidak suka, 2 = sangat tidak suka, $3=$ tidak suka, $4=$ agak tidak suka, $5=$ netral, $6=$ agak suka, $7=$ suka, $8=$ sangat suka, $9=$ amat sangat suka).

Tabel 1. Tingkat kepentingan setiap parameter

\begin{tabular}{clc}
\hline No & \multicolumn{1}{c}{ Parameter } & Bobot nilai \\
\hline 1 & Kadar air & 1 \\
2 & pH & 0,9 \\
3 & Aktivitas air & 0,3 \\
4 & Viskositas & 0,6 \\
5 & Warna: Tingkat kecerahan (L) & 0,6 \\
6 & Koordinat $\mathrm{a}^{*}$ & 0,6 \\
7 & Koordinat $\mathrm{b}^{*}$ & 0,4 \\
\hline
\end{tabular}

Analisis statistik

Data utama yang telah dihimpun dianalisis menggunakan program SPSS menggunakan Two-Way Analysis of Variance (ANOVA) dengan lama sterilisasi dan penambahan asam sitrat sebagai faktor dan dilanjutkan uji Duncan Multiple Range Test dengan taraf kepercayaan $95 \%(p<0,05)$. Data analisis dengan parameter terbaik kemudian dilanjutkan dengan uji sensoris yang analisisnya dilakukan menggunakan One-Way ANOVA.

\section{Hasil dan Pembahasan}

Kadar Air dan $\mathrm{pH}$

Tabel 2 menggambarkan pengaruh signifikan lama sterilisasi, penambahan asam sitrat, dan interaksinya terhadap kadar air. Air dapat bertindak sebagai katalis perantara dalam aktivitas biokimia bakteri, terutama dalam perombakan substrat. Selama proses retort, kadar air sampel menurun signifikan $(p<0,05)$ seiring dengan peningkatan waktu proses (Pal et al., 2018). Kinglsy et al. (2007) menjelaskan bahwa penurunan kadar air dapat

Tabel 2a. Sifat fisik dan kimia sambal andaliman dengan berbagai perlakuan

\begin{tabular}{|c|c|c|c|c|c|c|c|c|c|}
\hline \multirow{3}{*}{ Parameter } & \multicolumn{7}{|c|}{ Lama sterilisasi } & \multicolumn{2}{|c|}{$\begin{array}{l}\text { Pengaruh } \\
\text { signifikan }\end{array}$} \\
\hline & \multicolumn{3}{|c|}{20 menit } & \multicolumn{6}{|c|}{35 menit } \\
\hline & $\begin{array}{c}\text { konsentrasi } \\
\text { asam sitrat } \\
0 \%\end{array}$ & $\begin{array}{c}\text { konsentrasi } \\
\text { asam sitrat } \\
1 \%\end{array}$ & $\begin{array}{c}\text { konsentrasi } \\
\text { asam sitrat } \\
3 \%\end{array}$ & $\begin{array}{c}\text { konsentrasi } \\
\text { asam sitrat } \\
5 \%\end{array}$ & $\begin{array}{c}\text { konsentrasi } \\
\text { asam sitrat } \\
0 \%\end{array}$ & $\begin{array}{c}\text { konsentrasi } \\
\text { asam sitrat } \\
1 \%\end{array}$ & $\begin{array}{c}\text { konsentrasi } \\
\text { asam sitrat } \\
3 \%\end{array}$ & $\begin{array}{c}\text { konsentrasi } \\
\text { asam sitrat } \\
5 \%\end{array}$ & \\
\hline Kadar air & $\begin{array}{c}83,91^{d} \pm \\
5,66\end{array}$ & $\begin{array}{c}81,14^{c} \pm \\
4,74\end{array}$ & $\begin{array}{c}82,74^{\mathrm{cd}} \pm \\
4,98\end{array}$ & $\begin{array}{c}83,59 \mathrm{~d} \\
\pm 7,65\end{array}$ & $\begin{array}{c}76,60^{\mathrm{b}} \pm \\
2,21\end{array}$ & $\begin{array}{c}78,59^{b} \pm \\
2,23\end{array}$ & $\begin{array}{c}76,38^{\mathrm{b}} \pm \\
2,33\end{array}$ & $\begin{array}{c}73,10^{a} \pm \\
4,13\end{array}$ & $S, A, I$ \\
\hline $\mathrm{pH}$ & $\begin{array}{c}4,80^{\circ} \pm \\
0,07\end{array}$ & $\begin{array}{c}4,76^{c} \pm \\
0,03\end{array}$ & $\begin{array}{c}4,46^{b c} \pm \\
0,10\end{array}$ & $\begin{array}{c}4,74^{c} \pm \\
0,02\end{array}$ & $\begin{array}{c}4,15^{\mathrm{ab}} \pm \\
0,50\end{array}$ & $\begin{array}{c}4,10^{\mathrm{ab}} \pm \\
0,10\end{array}$ & $\begin{array}{c}3,96^{a} \pm \\
0,10\end{array}$ & $\begin{array}{c}4,07^{a b} \pm \\
0,01\end{array}$ & $S, A$ \\
\hline $\begin{array}{l}\text { Aktivitas } \\
\text { air }\end{array}$ & $\begin{array}{c}0,89^{\mathrm{b}} \pm \\
0,00\end{array}$ & $\begin{array}{c}0,92^{\mathrm{d}} \pm \\
0,00\end{array}$ & $\begin{array}{c}0,89^{\mathrm{b}} \pm \\
0,01\end{array}$ & $\begin{array}{c}0,85^{\mathrm{a}} \pm \\
0,04\end{array}$ & $\begin{array}{c}0,91^{c} \pm \\
0,03\end{array}$ & $\begin{array}{c}0,93^{d} \pm \\
0,03\end{array}$ & $\begin{array}{c}0,94^{\mathrm{e}} \pm \\
0,02\end{array}$ & $\begin{array}{c}0,91^{\circ} \pm \\
0,06\end{array}$ & $A, I$ \\
\hline Viskositas & $\begin{array}{c}4939^{c} \pm \\
491\end{array}$ & $\begin{array}{c}4369^{c} \pm \\
225\end{array}$ & $\begin{array}{c}4270^{\mathrm{b}} \pm \\
411\end{array}$ & $\begin{array}{c}4189^{a b} \pm \\
387\end{array}$ & $\begin{array}{c}4069^{a} \pm \\
289\end{array}$ & $\begin{array}{c}4139^{a b} \pm \\
277\end{array}$ & $\begin{array}{c}4039^{a} \pm \\
375\end{array}$ & $\begin{array}{c}6239^{d} \pm \\
454\end{array}$ & $S, A, I$ \\
\hline
\end{tabular}

$\mathrm{S}=$ pengaruh utama lama sterilisasi $(\mathrm{p}<0,05) ; \mathrm{A}=$ pengaruh utama penambahan asam sitrat $(\mathrm{p}<0,05) ; \mathrm{I}=$ interaksi antara lama sterilisasi dan penambahan asam sitrat $(p<0,05)$. Huruf yang sama pada baris yang sama menunjukkan bahwa tidak ada perbedaan signifikan $(p>0,05)$. 
Tabel 2b. Warna sambal andaliman dengan beberapa perlakuan

\begin{tabular}{|c|c|c|c|c|c|c|c|c|c|}
\hline \multirow{3}{*}{ Parameter } & \multicolumn{8}{|c|}{ Lama sterilisasi } & \multirow[t]{3}{*}{$\begin{array}{l}\text { Pengaruh } \\
\text { signifikan }\end{array}$} \\
\hline & \multicolumn{4}{|c|}{20 menit } & \multicolumn{4}{|c|}{35 menit } & \\
\hline & $\begin{array}{c}\text { konsentrasi } \\
\text { asam sitrat } \\
0 \%\end{array}$ & $\begin{array}{c}\text { konsentrasi } \\
\text { asam sitrat } \\
1 \%\end{array}$ & $\begin{array}{c}\text { konsentrasi } \\
\text { asam sitrat } \\
3 \%\end{array}$ & $\begin{array}{c}\text { konsentrasi } \\
\text { asam sitrat } \\
5 \%\end{array}$ & $\begin{array}{c}\text { konsentrasi } \\
\text { asam sitrat } \\
0 \%\end{array}$ & $\begin{array}{c}\text { konsentrasi } \\
\text { asam sitrat } \\
1 \%\end{array}$ & $\begin{array}{c}\text { konsentrasi } \\
\text { asam sitrat } \\
3 \%\end{array}$ & $\begin{array}{c}\text { konsentrasi } \\
\text { asam sitrat } \\
5 \%\end{array}$ & \\
\hline $\begin{array}{l}\text { Tingkat } \\
\text { kecerahan } \\
\text { (L) }\end{array}$ & $\begin{array}{c}36,99^{\mathrm{a}} \pm \\
1,14\end{array}$ & $\begin{array}{c}38,81^{\mathrm{c}} \pm \\
1,87\end{array}$ & $\begin{array}{c}38,05^{b} \pm \\
3,02\end{array}$ & $\begin{array}{c}38,04^{b} \pm \\
3,22\end{array}$ & $\begin{array}{c}53,95^{\mathrm{e}} \pm \\
2,53\end{array}$ & $\begin{array}{c}52,59^{d} \pm \\
2,84\end{array}$ & $\begin{array}{c}52,17^{d} \pm \\
2,78\end{array}$ & $\begin{array}{c}52,78^{d} \pm \\
1,37\end{array}$ & $S, A, I$ \\
\hline $\begin{array}{l}\text { Koordinat } \\
a^{\star} \\
\text { Koordinat } \\
b^{\star}\end{array}$ & $\begin{array}{c}12,53^{\mathrm{ab}} \pm \\
1,01 \\
28,45^{\mathrm{b}} \pm \\
2,54\end{array}$ & $\begin{array}{c}13,77^{\mathrm{ab}} \pm \\
1,00 \\
27,99^{\mathrm{b}} \pm \\
2,15\end{array}$ & $\begin{array}{c}13,05^{\mathrm{ab}} \pm \\
0,65 \\
27,99^{\mathrm{b}} \pm \\
2,11\end{array}$ & $\begin{array}{c}13,39^{\mathrm{b}} \pm \\
0,77 \\
27,88^{\mathrm{b}} \pm \\
2,35\end{array}$ & $\begin{array}{c}1,23^{\mathrm{a}} \pm \\
0,84 \\
25,18^{\mathrm{a}} \pm \\
1,78\end{array}$ & $\begin{array}{c}1,46^{\mathrm{a}} \pm \\
0,11 \\
24,94^{\mathrm{a}} \pm \\
2,34\end{array}$ & $\begin{array}{c}1,73^{\mathrm{a}} \pm \\
0,08 \\
25,14^{\mathrm{a}} \pm \\
2,57\end{array}$ & $\begin{array}{c}1,31^{\mathrm{a}} \pm \\
0,02 \\
25,64^{\mathrm{a}} \pm \\
2,54\end{array}$ & $\mathrm{~S}, \mathrm{~A}, \mathrm{I}$ \\
\hline
\end{tabular}

asam sitrat $(p<0,05)$; NS = tidak ada yang signifikan. Huruf yang sama pada baris yang sama menunjukkan bahwa tidak ada perbedaan signifikan $(p>0,05)$.

terjadi karena adanya penambahan asam sitrat yang melemaskan struktur jaringan dan meningkatkan efektivitas difusitas air. Kadar air terendah terdapat pada sambal andaliman dengan perlakuan sterilisasi 35 menit dan asam sitrat $5 \%$ yaitu sebesar $73,1 \%$. Kadar air pada sambal andaliman ini lebih tinggi dibandingkan dengan kadar air pada kadar air sambal andaliman yaitu 50,37$53,67 \%$ di penelitian Naibaho et al. (2020) dan saus lain yang memiliki rentang sebesar 28,14-59,6\% (Mehrin et al., 2020)

Data nilai pH (Tabel 2a) menunjukkan bahwa terdapat perbedaan signifikan pada sambal dengan lama sterilisasi dan penambahan asam sitrat yang berbeda. Sambal dengan lama sterilisasi 35 menit memiliki range $\mathrm{pH}$ yang lebih rendah $(3,96-4,15)$ daripada lama sterilisasi 20 menit $(4,46-4,80)$. Semakin tinggi kadar asam asetat yang ditambahkan dapat menghasilkan nilai $\mathrm{pH}$ yang menurun, serupa dengan penelitian (Chaethong dan Ponsawatmanit, 2015). Nilai $\mathrm{pH}$ yang lebih rendah dalam produk pangan menunjukkan umur simpannya yang lebih lama, karena $\mathrm{pH}$ dapat menjaga keseimbangan mikroorganisme dalam produk pangan. Nilai $\mathrm{pH}$ dalam penelitian ini serupa dengan berbagai varietas sambal dan saus, yaitu pada kisaran 4,00-5,21 (Sapers et al., 1984; Munhoz dan Schmidt, 2019). Nilai pH terbaik terdapat pada sambal dengan lama sterilisasi 30 menit dan $3 \%$ penambahan asam sitrat.

\section{Aktivitas Air}

Penambahan asam sitrat dan interaksi antara asam sitrat dan lama sterilisasi memberikan pengaruh signifikan terhadap aktivitas air (Tabel 2a). Perlakuan sambal yang menghasilkan aktivitas air terbaik adalah sambal dengan lama sterilisasi 20 menit dan asam sitrat $5 \%$. Aktivitas air memiliki korelasi dengan pertumbuhan mikroba, dimana aktivitas air yang tinggi dapat mempermudah pertumbuhan mikroba yang akan menyebabkan kerusakan produk. Bakteri penyebab penyakit karena makanan (foodborne disease) dapat tumbuh pada bahan pangan dengan aktivitas air di atas 0,85 (Sevenich et al., 2015).

\section{Viskositas}

Hasil penelitian menunjukkan bahwa terdapat interaksi antara lama sterilisasi dan penambahan asam sitrat. Pada sampel kontrol dan penambahan asam sitrat 1 dan 3\%, tidak terdapat perbedaan viskositas yang signifikan antara sampel dengan lama sterilisasi 20 menit dan 35 menit. Viskositas tertinggi terdapat pada sambal dengan lama sterilisasi 35 menit dan $5 \%$ asam sitrat Nilai viskositas sambal ini sesuai dengan viskositas sambal tempoyak yang dilaporkan oleh Pangastuti et al. (2020). Penurunan viskositas akibat peningkatan waktu retort diduga terjadi karena penurunan gaya kohesi antarmolekul yang menyebabkan ikatan melemah. Suhu retort dapat memberikan pengaruh ganda terhadap viskositas produk, yaitu meningkat dan menurun (Abbatemarco dan Ramaswamy, 1993).

\section{Warna}

Parameter warna $L^{*}$, $a^{*}$, dan $b^{*}$ (Tabel $2 b$ ) mengindikasikan bahwa warna sambal andaliman adalah hijau, yang menunjukkan dominasi pigmen klorofil pada cabai hijau. Pemanasan memiliki pengaruh signifikan $(p<0,05)$ terhadap parameter $L^{*}, a^{*}$, dan $b^{*}$. Perubahan ini dipengaruhi oleh dekstruksi pigmen dan browning nonenzimatis. Pemanasan dapat menyebabkan klorofil terdesktruksi dan berubah menjadi pheophytin sehingga mengakibatkan perubahan warna (Amiir et al., 2014). Degradasi pigmen selama proses termal mengikuti reaksi kinetik orde pertama dan pengaruh suhu terhadap konstanta $L^{*}$, $a^{*}$, dan $b^{*}$ mengikuti persamaan Arrhenius (Ahmed et al., 2002).

Parameter warna dapat dibagi menjadi 3 bagian, yaitu kecerahan (lightness/L*), koordinat $\mathrm{a}^{*}$, dan koordinat $b^{*}$ (Palus, 1998). Parameter lightness menunjukkan tingkat kecerahan pada bahan yang dianalisis. Semakin tinggi nilai L, maka tingkat kecerahan produk juga semakin tinggi. Hasil penelitian menunjukkan bahwa kedua perlakuan yaitu lama sterilisasi dan penambahan asam sitrat memberikan kontribusi kecerahan yang signifikan. Sambal dengan sterilisasi yang lama dan penambahan 
asam akan meningkatkan kecerahan, hal itu dikarenakan adanya perubahan klorofil menjadi pheophytin akibat perubahan $\mathrm{pH}$ dan juga panas (Amiir et al., 2014; Koca et al., 2007). Sambal dengan hasil nilai kecerahan terbaik adalah sambal dengan lama sterilisasi $20 \%$ tanpa penambahan asam sitrat.

Tabel 3. Pemilihan perlakuan terbaik dengan metode indeks efektivitas

\begin{tabular}{lcc}
\hline Peringkat & Perlakuan & Skor \\
\hline 8 & $\begin{array}{c}\text { Asam sitrat 0\%; lama } \\
\text { sterilisasi 20 menit } \\
\text { Asam sitrat 1\%; lama } \\
\text { sterilisasi 20 menit }\end{array}$ & 1,071 \\
5 & $\begin{array}{c}\text { Asam sitrat 3\%; lama } \\
\text { sterilisasi 20 menit }\end{array}$ & 2,162 \\
6 & $\begin{array}{c}\text { Asam sitrat 5\%; lama } \\
\text { sterilisasi 20 menit }\end{array}$ & 2,099 \\
3 & $\begin{array}{c}\text { Asam sitrat 0\%; lama } \\
\text { sterilisasi 35 menit }\end{array}$ & 3,608 \\
4 & $\begin{array}{c}\text { Asam sitrat 1\%; lama } \\
\text { sterilisasi 35 menit }\end{array}$ & 3,384 \\
& $\begin{array}{c}\text { Asam sitrat 3\%; lama } \\
\text { sterilisasi 35 menit }\end{array}$ & 3,865 \\
& Asam sitrat 5\%; lama \\
sterilisasi 35 menit & 5,326 \\
\hline
\end{tabular}

Koordinat $a^{*}$ merupakan parameter warna merahhijau, dimana kecenderungan nilai positif merujuk pada warna kemerahan, dan nilai negatif merujuk pada warna hijau (Palus, 1998). Hasil penelitian menunjukkan perbedaan signifikan antara perlakuan lama sterilisasi dan penambahan asam sitrat, serta interaksinya. Hasil koordinat a terbaik adalah pada lama sterilisasi 20 menit tanpa penambahan asam sitrat, yang menghasilkan $a^{*}$ sebesar $12.53 \%$.

Koordinat $b^{*}$ merupakan parameter warna kuningbiru, dimana kecenderungan nilai positif merujuk pada warna kuning, dan nilai negatif merujuk pada warna biru (Palus, 1998). Hasil penelitian menunjukkan bahwa perlakuan lama sterilisasi dan penambahan asam sitrat serta interaksinya tidak menghasilkan perbedaan nyata pada koordinat $b^{*}$.

\section{Pemilihan Sampel Terbaik}

Pemilihan sampel terbaik dilakukan menggunakan metode indeks efektivitas (DeGarmo et al., 1984). Hasil pemilihan sampel (Tabel 3) menunjukkan bahwa dua sambal retort terpilih adalah: (1) sambal dengan penambahan asam sitrat 3\%, lama sterilisasi 35 menit; dan
(2) sambal dengan penambahan asam sitrat $5 \%$, lama sterilisasi 35 menit. Kedua sambal ini kemudian dilakukan pengamatan sensoris bersama dua sambal lainnya, yaitu sambal kontrol (sambal andaliman tanpa sterilisasi dan tanpa asam sitrat), dan sambal dengan sterilisasi (tanpa asam sitrat).

\section{Analisis Sensoris}

Tabel 4 merupakan hasil analisis sensoris yang telah dilakukan pada 35 panelis. Uji yang dilakukan adalah uji hedonik dengan 9 skala, dengan skala tertinggi adalah 9 (amat sangat suka), dan skala terendah (amat sangat tidak suka). Hasil analisis yang diolah melalui SPSS menunjukkan bahwa terdapat empat parameter sensoris yang tidak berbeda nyata antar perlakuan, yaitu warna, tekstur, aroma, dan overall. Namun, terdapat perbedaan nyata pada parameter rasa. Dalam parameter rasa, diketahui bahwa sambal dengan penambahan asam sitrat 3\% dan lama sterilisasi 35 menit tidak menunjukkan perbedaan nyata dengan sambal kontrol. Hal tersebut menunjukkan bahwa perlakuan terbaik pada produk sambal berkemasan retort adalah sambal dengan perlakuan tersebut. Beberapa studi pada produk retort menunjukkan hasil evaluasi sensoris yang tidak berbeda nyata dibanding produk kontrol (Pal et al., 2018; Kumar et al., 2017).

\section{Kesimpulan}

Berdasarkan hasil penelitian, diketahui bahwa perlakuan lama sterilisasi dan penambahan asam sitrat dapat mempertahankan kualitas sambal andaliman. Melalui beberapa tahapan pengujian, diketahui bahwa sambal dengan penambahan asam sitrat 3\% dan lama sterilisasi 35 menit merupakan sambal dengan kombinasi perlakuan terbaik. Hasil ini menunjukkan bahwa sambal dengan perlakuan tersebut memiliki potensi yang tinggi dalam inovasi baru produk pangan tradisional. Diperlukan penelitian lanjutan mengenai umur simpan sambal terpilih untuk mengetahui lebih lanjut daya tahan sambal andaliman berkemasan retort dalam suhu ruang.

\section{Ucapan Terima Kasih}

Penelitian ini disponsori oleh Institut Teknologi Sumatera dalam kerangka program Hibah Penelitian ITERA Smart Tahun 2019 dengan Nomor Kontrak B/351/IT9.C1/PT.01.03/2019.

Tabel 4. Hasil evaluasi sensoris sambal andaliman berkemasan retort

\begin{tabular}{lcccc}
\hline \multirow{2}{*}{ Parameter } & Kontrol & $\begin{array}{c}\text { Asam sitrat 0\%, lama } \\
\text { sterilisasi 35 menit }\end{array}$ & $\begin{array}{c}\text { Asam sitrat 3\%, lama } \\
\text { sterilisasi 35 menit }\end{array}$ & $\begin{array}{c}\text { Asam sitrat 5\%, lama } \\
\text { sterilisasi 35 menit }\end{array}$ \\
\cline { 2 - 5 } Warna & $6,90 \pm 0.94$ & $7,19 \pm 0,98$ & $6,90 \pm 0,94$ & $6,71 \pm 0,84$ \\
\hline Tekstur & $6,29 \pm 0,90$ & $6,48 \pm 0,81$ & $6,29 \pm 0,78$ & $6,76 \pm 0,94$ \\
\hline Aroma & $5,86 \pm 1,01$ & $5,90 \pm 1,18$ & $6,29 \pm 1,27$ & $6,38 \pm 0,92$ \\
\hline Rasa & $7,05^{\mathrm{b}} \pm 0,92$ & $6,76^{\mathrm{ab}} \pm 1,26$ & $6,86^{\mathrm{b}} \pm 0,91$ & $6,14^{\mathrm{a}} \pm 0,96$ \\
\hline Overall & $7,05 \pm 0,87$ & $6,90 \pm 0,77$ & $6,95 \pm 0,87$ & $7,00 \pm 0,83$ \\
\hline
\end{tabular}




\section{Daftar Pustaka}

Amiir, M., Ovissipour, M., Rasco, B., Tang, J., Sablani, S. 2014. Seasonality of the thermal kinetics of color changes in whole spinach (Spinacia oleracea) leaves under pasteurization conditions. International Journal of Food Properties 17(9):2012-2024. DOI:10.1080/10942912.2013.779701.

Abbatemarco, C., Ramaswamy, H. 1993. Heating behavior and quality factor retention in a canned model foods as influenced by thermal processing in a rotary retort. Journal of Food Quality 16(4):273-285. DOI:10.1111/j.1745-4557.1993.tb00113.

Ahmed, J., Shivhare U.S., Ramaswamy, H.S. 2002. A fraction conversion kinetic model for thermal degradation of color in red chilli pureeand paste. Lebensmittel-Wissenschaft und -Technologie 35(1):497-503. DOI:10.1006/fstl.2002.0897.

Al-Baali, A.G., Farid, M.M. 2006. Sterilization of Food in Retort pouches. Springer, New York.

AOAC, 2000. Official Methods of Analysis $17^{\text {th }}$ Ed. AOAC International. Gaithersburg, USA.

Apichartsrangkoon, A., Srisajjalertwaja, S., Chaikham, P., Hirun, S. 2012. Physical and chemical properties of nam ping noom, a thai green-chili paste, following ultra-high pressure and thermal processes. High Pressure Research: An International Journal 33(1):83-95. DOI:10.1080/08957959.2013.765869.

Bindu, J., Ravishankar, C.N., Gopal, T.K.S. 2005. Shelf life evaluation of a ready-to-eat black clam (Villorita cyprinoides) product in indigenous retort pouches. Journal of Food Engineering 78(3):995-1000. DOI:10.1016/j.jfoodeng.2005.12.040.

Chaethong, K., Pongsawatmanit, R. 2015. Influence of sodium metabisulfite and citric acid in soaking process after blanching on quality and storage stability of dried chili. Journal of Food Processing and Preservation 39(6):2161-2170. DOI:10.1111/jpp. 12460.

DeGarmo, E.P., Sullivan, W.G., Canada, J.R. 1984. Engineering Economy. Seventh Edition, Macmillan, New York.

Gardjito, M. 2013. Bumbu, Penyedap, dan Penyerta Masakan Indonesia. Gramedia Pustaka Utama, Jakarta.

Gardjito, M., Putri, R.G., Dewi, S. 2017. Profil Struktur, Bumbu, dan Bahan dalam Kuliner Indonesia. Gadjah Mada University Press, Yogyakarta.

Harahap, A.U., Silaban, R. 2019. Mengenal Potensi Merica Batak: Andaliman (Zanthoxylum acanthopodium). Penerbit Puspantara, Medan.

Holanda, N.V., da Joyciane, S.G., Sandra, M.L., Dos, S., Marlene, N.D. 2018. Shelf life of artisanal dei-glace sauce. Food Science and Technology Campinas 38(3):480-484, 2018. DOI:10.1590/1678$457 X .37416$

Hsuan, K. 1978. Order and Families of Malayan Seed Plant. Singapore University Press, Singapore.
Kingsly, R.P., Goyal, R.K., Manikantan, M.R., llyas, S.M. 2007. Effects of pretreatments and drying air temperature on drying behaviour of peach slice. International Journal of Food Science \& Technology 42(1):65-69.

DOI:10.1111/j.13652621.2006.01210.x.

Koca, N., Karadeniz, F., Burdurlu, H.S. 2007. Effect of pH on chlorophyll degradation and colour loss in blanched green peas. Food Chemistry 100(2):609615. DOI:10.1016/j.foodchem.2005.09.079

Kumar, R., Harish, S., Subramanian, V., Kumar, S.S., Nadanasabapathi, S. 2017. Development and quality evaluation of retort processed RTE functional gluten free foxtail millet halwa. Croatian Journal of Food Science and Technology 9(2):114-121. DOI:10.17508/CJFST.2017.9.2.05.

Lim, J. 2011. Hedonic scaling: a review of methods and theory. Food Quality and Preference 22(8):733-747. DOI:10.1016/j.foodqual.2011.05.008.

Mehrin, S., Zakir, H.M., Seal, H.P., Akter, M. 2020. Nutritional quality and metallic health risk assessment of industrially processed tomato ketchups available in the markets of Bangladesh. European Journal of Nutrition \& Food Safety 12(3):67-78.

DOI:10.9734/EJNFS/2020/v12i330210.

Munhoz, K.A.S., Schmidt, F.L. 2019. The tomato paste quality attributes along the industrial processing chain. African Journal of Food Science 13(10):215224. DOI:10.5897/AJFS2019.1825

Naibaho, N.M., Damanik, N.S., Syauqi, A. 2020. Profil organoleptik sambal segar andaliman (Zanthoxylum acanthopodium DC) dan batang kecombrang (Etlingera elatior) muda. Journal of Tropical AgriFood

2(1):1-7. DOI:10.35941/jtaf.2.1.2020.3842.1-7.

Napitupulu, B., Simatupang, S., Sinaga, M. 2004. Potency of andaliman as traditional food additive of Batak ethnic North Sumatera. Seminar Nasional Peningkatan Daya Saing Pangan Tradisional, BB Pascapanen, Bogor, Indonesia.

Pal, U.S., Das, M., Nayak, R.N., Sahoo, N.R., Panda, M.K., Dash, S.K. 2018. Development and evaluation of retort pouch processed chhenapoda (cheese based baked sweet). Journal of Food Science and Technology 56(1):302-309. DOI:10.1007/s13197018-3490-6.

Palus, H. 1998. Representations of colour images in different colour spaces. In The Colour Image Processing Handbook (pp. 67-90). Springer, Boston.

Pangastuti, H.A., Permana, L., Mareta, D.T., Fitriani, V., Wahyuningtyas, A. 2020. Kajian sifat fisik, kimia, dan sensoris sambal tempoyak (durian terfermentasi) berkemasan retort pouch. Jurnal Teknologi Pertanian Andalas 24(2):157-165. DOI:10.25077/jtpa.24.2.157-165.2020. 
Rajan, S., Kulkarni, V.V., Chandirasekaran, V. 2014. Preparation and storage stability of retort processed chettinad chicken. Journal of Food Science and Technology 51(1):173-177. DOI:10.1007/s13197011-0477-y.

Ridho, M., Lindarto, D. 2018. The effect of andaliman fruit extract to blood glucose levels of mice with type I diabetes. Stem Cell Oncology: Proceedings of the International Stem Cell and Oncology Conference (ISCOC 2017).

Robertson, G.L. 2006. Food Packaging: Principles and Practice: Second Edition. CRC Press, Boca Raton.

Sapers, G.M., Phillips, J.G., DiVito, A.M. 1984. Corelation between $\mathrm{pH}$ and composition of foods comprising mixtures of tomatoes and low-acid ingredients. Journal of Food Science 49(1):233-235. DOI:10.1111/j.1365-2621.1984.tb13715.x.

Sevenich, R., Reineke, K., Hecht, P., Frohling, A., Rauh, C., Schluter, O., Dietrich, K. 2015. Impact of different water activities (aw) adjusted by solutes on high pressure high temperature inactivation of Bacillus amyloliquefaciens spores. Microbiology 6(1):1-11. DOI:10.3389/fmicb.2015.00689.

Sonangda, M., Sinaga, H., Limbong, L.N. 2019. Effect of ratio of andaliman (Zanthoxylum acanthopodium) with garlic and aging time on the quality of sambal tuk tuk. IOP Conference Series: Earth and Environmental Science 260(2019)012084. DOI:10/22146:10.1088/1755-1315/260/1/012084.

Suryanto, E., Sastrohamidjojo, H., Raharjo, S., Tranggono. 2004. Antiradical activity of andaliman (Zanthoxylum achanthopodium DC) fruit extract. Indonesian Food and Nutrition Progress 11(1). DOI:10.22146/jifnp.26.

Topno, P.N., Vinothini, Jayaprakash, S.H., Varadaiah, V., Sheshagiri, S. H., Srinivas, P. M., Naidu, M.M. 2011. Ginger-garlic paste in retort pouches and its quality. Journal of Food Process Engineering 36(1):1-8. DOI:10.1111/j.1745-4530.2011.00645.x.

Wardhani, D.H., Aryanti, N., Buchori, L., Cahyono, H. 2020. Quality degradation of local SME sambal during storage. Proceedings of 2nd International Conference on Chemical Process and Product Engineering (ICCPPE) 2019. DOI:10.1063/1.5140939.

Wijaya, C.H., Napitupula, F.I., Karnady, V., Indariani, S. 2018. A review of the bioactivity and flavor properties of the exotic spices "andaliman (Zanthoxylum acanthopodium DC). Food Reviews International 35(1):1-19. 